\title{
ВПРОВАДЖЕННЯ КРЕДИТНО-МОДУЛЬНОЇ СИСТЕМИ ОРГАНІЗАЦЇ̈ НАВЧАЛЬНОГО ПРОЦЕСУ ЯК ОСНОВИ ПІДГОТОВКИ ВИСОКОКВАЛІФІКОВАНОГО СПЕЦІАЛІСТА-СТОМАТОЛОГА
}

Н. І. Кукурудз

Івано-Франківський національний медичний університет

\section{INTRODUCTION OF CREDIT-MODULAR SYSTEM OF EDUCATIONAL PROCESS ORGANIZATION AS A BASIS OF TRAINING OF HIGHLY QUALIFIED SPECIALIST-DENTIST}

\author{
N. I. Kukurudz
}

\author{
Ivano-Frankivsk National Medical University
}

\begin{abstract}
У статті представлено впровадження кредитно-модульної системи на кафедрі терапевтичної стоматології Івано-Франківського національного медичного університету. Відображено основні заходи підготовки предмета, показані методи навчання й оцінки набутих знань та умінь студентів на основі комплексного застосування поточного контролю, діагностичних моделей і тестової перевірки знань.
\end{abstract}

The article presents the introduction of credit-modular system at the Department of Therapeutic Dentistry of Ivano-Frankivsk National Medical University. The main steps of subject preparation, the methods of teaching and assessment of gained knowledge and skills on the basis of complex use of current control, the diagnosis model and tests are presented.

Вступ. Болонський процес є ефективним інструментом гармонізації системи вищої освіти кожної країни, діяльність якої пов' язана з інтеграцією вищої освіти в загальноєвропейський простір. Свропейська кредитнотрансферна система покликана оптимізувати навчальний процес [2]. Стандарти європейської системи освіти, що сформульовані Болонською декларацією, вже щільно інтегрувалися в навчальнийпроцес у вищих навчальних закладах України, демонструючи свою доступність та ефективність. Оптимізація навчального процесу, в свою чергу, пов' язана зі зростанням вимогливості до студента, його вмінням аналізувати та засвоювати велику кількість інформації в обмежений термін з одночасним формуванням практичних навичок та вмінь [8].

До складу Свропейського науково-освітнього об' єднання Україна увійшла, як відомо, у 2005 році [9]. Згідно з наказом МО3 України [7], із 2010 -2011 навчального року введена кредитно-модульна система організації навчального процесу на стоматологічних факультетах при підготовці майбутніх лікарів-стоматологів, у тому числі й на кафедрі терапевтичної стоматології Івано-Франківського національного медичного університету.

Навчаючи студентів відповідно до вимог Болонської системи, колектив кафедри з розумінням оцінює необхідність зростання вимогливості і до викладача, на відповідальності якого є організація навчання в такий спосіб, щоб студент умів самостійно активно мислити, аналізувати засвоєний матеріал із використанням попередніх базових знань, різних джерел наукової інформації та клінічних ситуацій. Відповідно до даних літератури такі методи викладання називаються активними [5]. За таким принципом повинні навчатися майбутні лікарі $[1,6]$. Адже саме цілісність організму людини передбачає самостійне, творче вирішення пізнавальних та практичних завдань і їх інтегрування.

Обов'язковим компонентом навчального процесу на кафедрі $\epsilon$ контроль результатів навчання, рівня знань студентів, який повинен відповідати освітньому стандарту нашої дисципліни - терапевтична стоматологія.

Основна частина. Основною метою педагогічного процесу на кафедрі є забезпечення якості підготовки предмета 3 аналітичною обробкою навчального матеріалу, об' єктивною оцінкою набутих знань та умінь студентів на основі комплексного застосування методів перевірки знань, поточного і тестового контролю та використання діагностичних моделей. Усі засоби перевірки проводяться за допомогою різних форм, методів та прийомів. 
Важливе значення з усіх перевірок на кафедрі належить поточному контролю. Він дозволяє регулярно керувати діяльністю студентів, мати безперервну інформацію про хід і якість засвоєння навчального матеріалу, оперативно вносити зміни до навчання. Поточна перевірка не тільки контроль, але й грунтовне навчання, оскільки вона пов'язана з закріпленням, повторенням і аналізом навчального матеріалу та інтеграцією зі знаннями, набутими при вивченні базових дисциплін (анатомія, фізіологія, гістологія, фармакологія, мікробіологія тощо).

Серед методів контролю важлива роль належить тестовій перевірці знань, яка має ряд переваг перед традиційними формами. Вона природно вписується в сучасні педагогічні концепції, дозволяє раціональніше використовувати час, швидше встановити зворотний зв' язок, визначити результати засвоєння матеріалу, вловити найтиповіші упущення чи неточності в знаннях і внести до них корективи. Дуже важливо, що при тестовому контролі одночасно проводиться перевірка знань студентів усієї групи, що формує в них мотивацію для підготовки до кожного заняття й одночасно їх дисциплінує.

Досвід нашої роботи показав, що чим краще організована перевірка, тим більше можливостей для закріплення матеріалу, активізації та розвитку пізнавальної діяльності студентів.

Проте використання тестового контролю має ряд недоліків. Швидко для студентів основною метою стає поверхневе вивчення дисципліни, недостатньо, не по-справжньому вивчається кожна конкретна тема й предмет у цілому. Очевидно, майже немає тестів, за допомогою яких можна перевірити уміння логічно мислити, міркувати з використанням базових знань, глибокого розуміння патогенезу захворювання, різних ланок його клінічного перебігу з визначенням на цій основі індивідуального патогенетичного лікування хворого.

При цьому дещо знижується й кваліфікація викладача. Хоч викладач і звільняється від рутинної роботи, проте перевірка тестових завдань відбувається в автоматичному режимі і не дає належного професійного навантаження.

Враховуючи вищесказане, навчальний простір, що охоплюється тестами, складає на кафедрі терапевтичної стоматології відповідно частину навчального предмета.

Поточний і тестовий контроль знань проводиться регулярно, поєднується 3 практичною роботою на заняттях (фантоми для відпрацювання практичних навиків).
Запорукою успішного засвоєння студентами навчального матеріалу на практичних заняттях є розуміння цього матеріалу. Необхідно підкреслити, що вивчення студентами терапевтичної стоматології охоплює тривалий період навчання з II курсу й до його завершення. Пропедевтика терапевтичної стоматології передує роботі студента безпосередньо 3 хворим. Саме для покращення розуміння та засвоєння навчального матеріалу викладачі кафедри терапевтичної стоматології під час проведення практичних занять, окрім демонстрації хворих, широко використовують завчасно підготовлений наочний матеріал, зокрема діагностичні моделі зуба. Діагностична модель у стоматології - це точна, як правило, гіпсова копія зуба або щелепи хворого, яка слугує в першу чергу для постановки та уточнення діагнозу, планування етапів відновлення, контролю лікування, яке проводиться $[3,4]$. У навчальному процесі діагностична модель щелепи дозволяє вирішити основні питання пізнання та розуміння - “краще один раз побачити, ніж сто разів почути".

Викладачі кафедри широко користуються демонстраційно-навчальними моделями, на яких відображені патологічні стани твердих тканин зуба (карієс, патологічна стертість зубів), патологія прикусу та аномалії положення окремо взятих зубів. Демонстрація та огляд таких моделей дозволяють студентам краще засвоїти та зрозуміти теоретичний матеріал практичного заняття. Демонстраційно-навчальні моделі виготовляються і підбираються заздалегідь для конкретних цілей педагогічного процесу. При цьому фантом із різними видами патології зубощелепної системи оглядається студентами з усіх боків, тобто забезпечується об'ємна демонстрація, що дуже зручно. При цьому створюються оптимальні умови для самостійної роботи студентів, яка розглядається як один із способів активного, цілеспрямованого здобуття студентом нових знань, умінь та навичок. Такий вид навчання сприяє систематизації, закріпленню та поглибленню знань, розвитку пізнавальних здібностей студента, формуванню самостійності, самовдосконаленню та самореалізації і значно полегшує засвоєння навчального матеріалу.

Використовуються також контрольно-навчальні моделі, які дають можливість викладачу проконтролювати правильність проведення діагностики студентами, оцінити якість застосування тієї чи іншої практичної навички, а потім вказати студентам на помилки чи недоліки проведених маніпуляцій, наприклад, під час препарування твердих тканин зуба й формування каріозної порожнини. Демонстраційні моделі 
щелеп, на яких зафіксовано стан після застосування певної практичної навички, дозволяють викладачу проконтролювати об'єм, ефективність, правильність і результат виконання маніпуляцій студентами, що $€$ необхідним елементом контролю навчання та оцінки правильності виконання маніпуляції.

Для кращої реалізації самостійної роботи на кафедрі розроблені методичні матеріали, що дає можливість студентові перевірити рівень знань та провести самоконтроль засвоєння матеріалу.

Важливою умовою інноваційної освіти на кафедрі терапевтичної стоматології є створення студентам умов для оволодіння навиками проведення наукових досліджень. Вагоме місце в цьому аспекті належить роботі студентів у студентських наукових гуртках.

\section{Література}

1. Бадмаев Б. Ц. Методика преподавания психологии / Б. Ц. Бадмаев. - Режим доступу : http: // www.twirpx.com/ file/160426/

2. Журавський В. Болонський процес : головні принципи входження в Свропейський простір вищої освіти / В. Журавський, М. Згуровський. -К. : Політехніка, 2003.-200 с.

3. Клемин В. А. Диагностическая модель челюсти / В. А. Клемин.- М., 2006. -256 с.

4. Клочан С. М. Досвід використання діагностичних моделей щелеп у навчальному процесі на кафедрі ортопедичної стоматології / С. М. Клочан // Современная стоматология. -2009. - № 1. - С. 140-142.

5. Махотин Д. А. Интерактивное обучение на уроках экономики / Д. А. Махотин. - Режим доступу : http: // som.fio.ru / getblob.asp?id $=10017463$

6. Мілерян В. Є. Методичні основи підготовки та проведення навчальних занять в медичних вузах : метод. посібник
При цьому забезпечується розвиток відповідного наукового стилю клінічного мислення та оволодіння методологією нововведень у медичній сфері. Все це підвищує якість вивчення студентами різних розділів, тем і дисципліни у цілому.

Для виявлення кінцевих результатів навчання використовується підсумковий контроль - інтегруючий, що дає можливість оцінити в цілому глибину знань вивченого студентом матеріалу.

Висновок. Застосування активних методів навчання, зокрема поточного контролю в письмовій та усній формах у поєднанні з тестовим контролем знань, широке впровадження діагностичних моделей та самостійної роботи студентів складають основу оптимального вивчення пропедевтики терапевтичної стоматології.

/ В. С. Мілерян. -К. : Хрещатик, 2004. -80 с.

7. Про затвердження та введення нового навчального плану підготовки фахівців освітньо-кваліфікаційного рівня “спеціаліст” кваліфікаціі “лікар-стоматолог” у вищих навчальних закладах IV рівня акредитації за спеціальністю “Стоматологія” : наказ МОЗ 07.12.2009 № 928 (зі змінами, внесеними згідно з наказом Міністерства охорони здоров’я України № 541 (v0541282-10) від 08.07.2010).

8. Організація самостійної роботи студентів на кафедрі дитячих хвороб у контексті Болонського процесу / А. Б. Волосянко, Л. Я. Іванишин, О. Б. Синоверська [та ін.] // Архів клінічної медицини. -2009. - № 1 (15). - С. 88-89.

9. Підаєв А. В. Болонський процес у Свропі. Що це таке і чи потрібний він Україні? Чи можлива інтеграція медичної освіти України в Свропейський освітній простір? / А. В. Підаєв, В. Г. Передерій. - Одеса : Одес. держ. мед. ун-т, 2004. -190 с. 